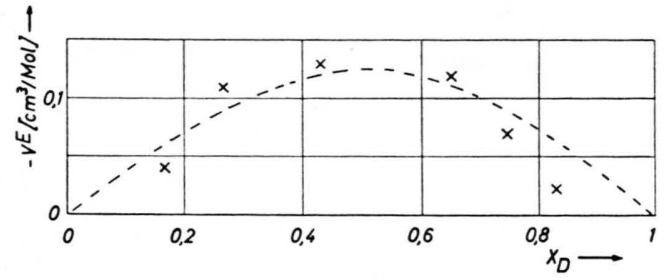

Abb. 7. Mittleres molares Zusatzvolumen des Systems Benzol-Diphenylmethan.
Dichte der Mischungen Benzol-Diphenylmethan bei $35^{\circ} \mathrm{C}$ (Tab. 8)

Da die Theorien auch Aussagen über die Volumenänderung beim Mischen geben können, wurden bei diesem System bei $35{ }^{\circ} \mathrm{C}$ die Dichten gemessen. Das damit berechnete Exzeßvolumen ist in Abb. 7 dargestellt.

Der Deutschen Forschungsgemeinschaft, dem Fonds der Chemie und den Farbenfabriken Bayer, Werk Uerdingen, sind wir für Bereitstellung von Mitteln zu groBem Dank verpflichtet.

\title{
The Thermoelectric Power in Molten and Solid Silver Nitrate*
}

\author{
Cesare Sinistri \\ Institute of Physical Chemistry, University of Pavia, Italy \\ (Z. Naturforschg. 20 a, 1045-1047 [1965] ; received 8 May 1965)
}

\begin{abstract}
In a silver electrodes thermocell the thermoelectric power $\varepsilon$ of solid $\beta$ and liquid silver nitrate is measured. The following values are obtained $\left(t_{\mathrm{m}}\right.$ is the average temperature of the system in centigrade) :

solid (from 160 to $209,4{ }^{\circ} \mathrm{C}$ ): $\quad \varepsilon=-237 \mu \mathrm{V}$ degree $^{-1}$, liquid (from 209,4 to $350^{\circ} \mathrm{C}$ ) : $\quad \varepsilon=\left(-304-0,077 t_{\mathrm{m}}\right) \mu \mathrm{V}$ degree $^{-1}$.

The entropies of transport of the silver and nitrate ions in silver nitrate have been calculated at different temperatures.
\end{abstract}

As part of a larger program, it has been necessary to take measurements on the thermocell:

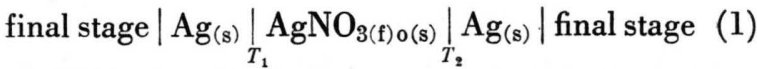
in the temperature range from 160 to $350{ }^{\circ} \mathrm{C}$, covering thus the solid $\beta$ phase of the $\mathrm{AgNO}_{3}$ from 160 to $209,4{ }^{\circ} \mathrm{C}$ and the liquid phase from the latter temperature upwards.

Apart from an indicative value supplied by PoINCARÉ $^{1}$ in 1890 and some data reported by Holtan $^{2}$ in graph form, values of the thermal emf of this thermocell, limited to the liquid state, have been furnished by Sundheim et al. for four distinct temperatures comprised between 240 and $307^{\circ} \mathrm{C}$ in a first report ${ }^{3}$ and for $310^{\circ} \mathrm{C}$ in a second report ${ }^{4}$.

\section{Experimental}

The measuring cell, made of pyrex, was of a tubular squared $\sqcup$ shape, with one arm covered by a glass sleeve. In the interspace between that arm of the cell

* Work carried out with the aid of the Consiglio Nazionale delle Ricerche (Rome).

1 L. Poincaré, Ann. chim. phys. [6] 21, 289 [1890].

2 H. Holtan, Dissertation, Utrecht 1953. and the sleeve are located resistences with anti-inductive coils connected through a Variac to a voltage stabilizer. The cell was located in an aluminium block made of three pieces, and the whole was placed in a thermostat oven of high capacity. Two electrode holders, fixed by asbestous plugs, held the chromel-alumel thermocouples and the silver electrodes. The latter were constructed in such a way that the contact with the silver nitrate was located at the small areas where the thermocouples measured the temperature. Differences of temperature, comprised between approximately 5 and $40{ }^{\circ} \mathrm{C}$, were created between the two electrodes. The potential difference $\Delta \Phi$, measured at zero current, showed strict proportionality to $\Delta T$.

Stationary conditions were reached in about $15-20$ minutes. Each group of measurements comprised about $7-9$ determinations, each of these being the average of at least four readings. The measurements were made in the sense of both heating and cooling. Each loading of the thermocell was used for only one group of determinations.

In the measurements on solid $\beta$ phase $\mathrm{AgNO}_{3}$ (160 to $209,4{ }^{\circ} \mathrm{C}$ ) the technique adopted was that of melting the salt within the cell and then leaving the whole to cool to the temperature at which one wished to take

${ }^{3}$ B. R. Sundheim and J. Rosenstreich, J. Phys. Chem. 63, 419 [1959].

4 R. Schneebaum and B. R. Sundheim, Discussions Faraday Soc. 32, 197 [1961] 
the measurement. By this procedure perfectly reproducible values were obtained.

In order to determine the emf a potentiometer of the K-3 type was used in junction with an electronic D-C null detector (Leeds \& Northrup). The silver nitrate used was a C. Erba product. The silver electrodes were made of a wire $(0.4 \mathrm{~mm} \phi)$ of at least 99.99\% purity.

\section{Results and Discussion}

The experimental results obtained for the thermopile (1) are reported in Table 1 where are shown, for the two phases investigated, the values of $\varepsilon$ ( $\equiv \Delta \Phi / \Delta T$ ) and the corresponding temperature

\begin{tabular}{|c|c|c|}
\hline & $-\varepsilon \mu \mathrm{Vdeg} .{ }^{-1}$ & $\begin{array}{l}\text { Field of } \\
t_{\mathrm{m}}\left({ }^{\circ} \mathrm{C}\right)\end{array}$ \\
\hline $\begin{array}{c}\mathrm{AgNO}_{3} \text { phase } \beta \\
\text { from } 160 \text { to } 209,4^{\circ} \mathrm{C}\end{array}$ & $\begin{array}{l}237 \pm 2 \\
237 \pm 3 \\
238 \pm 2 \\
237 \pm 1\end{array}$ & \multirow[t]{2}{*}{$\begin{array}{l}168-185 \\
193-200 \\
170-200 \\
174-194\end{array}$} \\
\hline Mean value & $237 \pm 2$ & \\
\hline $\begin{array}{c}\mathrm{AgNO}_{3} \text { liquid } \\
\text { from } 209,4 \text { to } 350^{\circ} \mathrm{C}\end{array}$ & $\begin{array}{l}322 \pm 2 \\
323 \pm 2 \\
324 \pm 2 \\
325 \pm 2 \\
327 \pm 1 \\
327 \pm 2 \\
328 \pm 2 \\
331 \pm 2\end{array}$ & $\begin{array}{l}215-235 \\
232-248 \\
247-263 \\
271-287 \\
287-302 \\
289-313 \\
306-320 \\
329-347\end{array}$ \\
\hline \multicolumn{3}{|c|}{$\varepsilon=-304-0,077 \cdot t_{\mathrm{m}}\left(t_{\mathrm{m}}\right.$ in ${ }^{\circ} \mathrm{C}, \varepsilon$ in $\left.\mu \mathrm{Vdeg} .^{-1}\right)$} \\
\hline
\end{tabular}

Table 1. Values of $\varepsilon$ for the thermocell $\mathrm{Ag} / \mathrm{AgNO}_{3} / \mathrm{Ag}$.

ranges $\left(t_{\mathrm{m}}\right.$ is the average temperature between the two electrodes). At the foot of the table appears the equation of the straight line which interpolates the experimental data for the liquid phase according to the method of least squares.

All results are represented in Fig. 1 where the experimental values reported by Sundheim et al. ${ }^{3,4}$ appear also.

In previous works it has been shown how one can develop a simple theory of thermocells with fused salts on the basis of the thermodynamics of the irreversible processes, should one adopt the Hitronf system of reference ${ }^{5,6}$. With the assumption that the hotter electrode is positive, for the thermocell

5 H. Schönert and C. Sinistri, Z. Elektrochem. 66, 413 [1962].

${ }^{6}$ C. Sinistri, Ric. Sci., Teil II-A, 32, 492 [1962].

7 In the following the word "ion" is understood in the sense of "ion constituent" as already discussed previously ${ }^{5,6}$.

8 P. F. Meads, W. R. Forsythe, and W. F. Giauque, J. Amer. Chem. Soc. 63, 1902 [1941].

9 F. M. Jaeger, E. Rosenbohm, and W. A. Veenstra, Proc. Koninkl. Ned. Akad. Wetenschap. 36, 291 [1933].

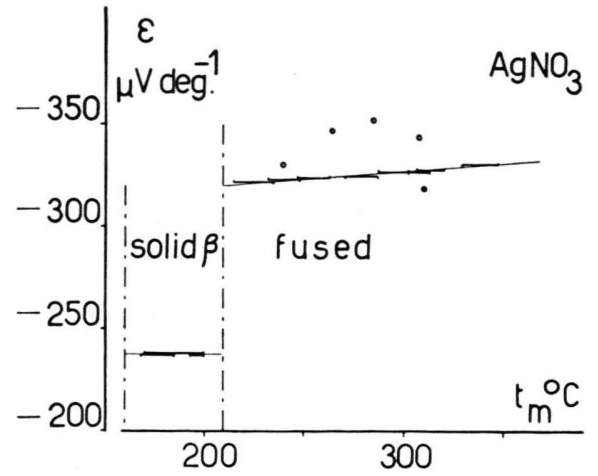

Fig. 1. Thermoelectric power of solid and fused $\mathrm{AgNO}_{3}$. $\sqcup$ present work; O Sundheim and Rosenstreich ${ }^{3}$; - Schneebaum and Sundheim ${ }^{4}$.

(1) the following relation is valid:

$$
\mathcal{F} \varepsilon=S_{\mathrm{Ag}}-S_{\mathrm{Ag}^{+}}^{*}-S_{\mathrm{e}}^{*} \quad\left(\text { for } T_{\mathrm{m}}=T_{1}+\Delta T / 2\right. \text { ) }
$$

where $\mathcal{F}$ is the Faraday's constant; $\varepsilon$ ( $\equiv \Delta \Phi / \Delta T$ ) is the coefficient of temperature of the thermal emf $\Delta \Phi ; S_{\mathrm{Ag}}$ is the entropy of metallic silver; $S_{\mathrm{Ag}^{+}}^{*}$ is the entropy of transport of the silver ion ${ }^{7}$ defined by: $S_{\mathrm{Ag}^{+}}^{*} \equiv Q_{\mathrm{Ag}^{+}}^{*} / T+S_{\mathrm{Ag}^{+}}$as a function of the heat of transport $Q_{\mathrm{Ag}}^{*}$ and of the entropy $S_{\mathrm{Ag}^{+}}$of the silver ion; $S_{\mathrm{e}}^{*}$ is the entropy of transport of the electron.

Since the simple relation

$$
S_{\mathrm{Ag}^{+}+}^{*} S_{\mathrm{NO}_{3}}^{*}=S_{\mathrm{AgNO}_{3}}
$$

is valid ${ }^{5,6}\left(S_{\mathrm{AgNO}_{3}}\right.$ is the entropy of the $\mathrm{AgNO}_{3}$ salt), from (2) and (3) it is possible to evaluate $S_{\mathrm{Ag}^{+}}^{*}$ and $S_{\mathrm{NO}_{3}}^{*}$ at different temperatures when $\varepsilon$ is measured and the quantities $S_{\mathrm{e}}^{*}, S_{\mathrm{Ag}}$ and $S_{\mathrm{AgNO}_{3}}$ are known.

Sundheim ${ }^{3}$ has calculated $S_{\mathrm{e}}^{*}$ to be equal to 0.03 u. e. for silver at $500^{\circ} \mathrm{K}$. The term $S_{\mathrm{e}}^{*}$ has therefore been neglected as certainly inferior to the experimental errors. The value of $S_{\mathrm{Ag}}$ can be obtained from the experimental specific heat data of Meads et al. ${ }^{8}$ up to $25{ }^{\circ} \mathrm{C}$ and of Jaeger et al. ${ }^{9}$ and of Lyashenko ${ }^{10}$ for higher temperatures. The entropy $S_{\mathrm{AgNO}_{3}}$ has been evaluated from the measurements of SMITH et al. ${ }^{11}$ up to room temperature, and from the recent determinations made by JANZ and KELLY ${ }^{12}$ for higher temperatures.

10 Values reported by D. R. Stull and G. C. Sinke, Thermodynamic Properties of the Elements, Ed. Amer. Chem. Soc. 1956, p. 185.

11 W. V. Sмith, O. L. I. Brown, and K. S. Pitzer, J. Amer. Chem. Soc. 59, 1213 [1937].

12 G. J. Janz and F. J. Kelly, J. Phys. Chem. 67, 2848 [1963]. 


\begin{tabular}{|c|c|c|}
\hline$t^{\circ} \mathrm{C}$ & $S_{\mathrm{Ag}}^{\star}{ }^{+}$ & $S_{\mathrm{NO}_{3}-}^{\star}$ \\
\hline 160 & 18,0 & 25,8 \\
180 & 18,2 & 26,5 \\
200 & 18,5 & 27,1 \\
220 & 20,7 & 32,1 \\
240 & 21,0 & 32,9 \\
260 & 21,3 & 33,7 \\
280 & 21,5 & 34,5 \\
300 & 21,8 & 35,2 \\
320 & 22,1 & 35,9 \\
340 & 22,3 & 36,6 \\
\hline
\end{tabular}

The results obtained for the values of $S_{\mathrm{Ag}^{+}}^{*}$ and $S_{\mathrm{NO}_{3}}^{*}$ as functions of the temperature are schematically shown in Table 2 .

The values regarding the solid phase of silver nitrate have been calculated, still holding valid the measurements of TUBAND and EGGERT ${ }^{13}$, who conclude that silver nitrate is an ionic conductor.

Table 2. Values of the entropies of transport (in cal/mole deg.) of the silver and nitrate ions in $\mathrm{AgNO}_{3}$ at different temperatures.

13 C. Tuband and S. Eggert, Z. Anorg. Chem. 110, 196 [1920].

\title{
Eine Methode zur Herstellung dünner Schichten anorganischer Salze
}

\author{
J. Demny * \\ Physikalisches Laboratorium Mosbach ** \\ (Z. Naturforschg. 20 a, 1047-1050 [1965] ; eingegangen am 19. Mai 1965)
}

\begin{abstract}
Die Methode (Sandwich-Methode) besteht darin, daß zwischen zwei Folien verdünnte Salzlösungen präpariert werden. Aus diesen Flüssigkeitslamellen kristallisieren die Salze vorwiegend als dünne Plättchen, da die Wachstumsrichtung in der dritten Dimension weitgehend unterdrückt wird. Alkali- und Ammoniumhalogenide lassen sich danach leicht in Form dünner, im Elektronenmikroskop durchstrahlbarer Folien herstellen. Bei $\mathrm{CsCl}$ und den Ammoniumhalogeniden treten stärkere Abweichungen in den Kristallgitterdimensionen auf, die durch die spezielle Präparationsmethode bedingt sind.
\end{abstract}

Für die Herstellung dünner, im Elektronenmikroskop durchstrahlbarer Folien anorganischer Verbindungen gibt es kein so allgemeines Verfahren, wie es z. B. das Elektropolieren für Metalle darstellt. Es sind bisher mehrere zum Teil recht unterschiedliche Präparationsmethoden für dünne Schichten anorganischer Salze bekannt geworden, die jedoch oft in ihrer Anwendung auf einige wenige Verbindungen beschränkt sind. So konnte Möllenstedt ${ }^{1}$ durch chemische Reaktion zwischen $\mathrm{KJ}$ - und $\mathrm{Pb}\left(\mathrm{NO}_{3}\right)_{2}$ Lösung $\mathrm{PbJ}_{2}$ in Form einkristalliner Plättchen erhalten. Schüller und Amelinckx ${ }^{2}$ stellten durch Abätzen dünner $\mathrm{CaF}_{2}$-Plättchen durchstrahlbare Folien her. Y AGI und Honso $^{3}$ berichteten kürzlich über dünne NaCl-Kristalle, die durch starke Elektronenbestrahlung dickerer Kristalle im Elektronenmikro-

* Neue Anschrift: BBC, Abt. ZFL, Heidelberg.

* V 104/65. Angeschlossen der Technischen Hochschule Karlsruhe und der Arbeitsgemeinschaft Industrieller Forschungsvereinigungen.

1 G. Möllenstedt, Optik 10, 72 [1953].

2 E. Schüller u. S. Amelinckx, Naturwiss. 47, 491 [1960].

3 K. YAGI U. G. Honso, J. Phys. Soc. Japan 19, 1892 [1964].

4 G. Haase, F. Granzer u. F. Zörgiebel, Z. Angew. Phys. 18, 120 [1964]. skop erzeugt wurden. Auch die Ultramikrotomie ist als Präparationsverfahren bekannt geworden ${ }^{4}$. Universeller anwendbar sind die Verfahren, die auf der Kristallisation aus wäßrigen Lösungen beruhen. Komoda und Sakata ${ }^{5}$ erhielten durch Aufsprühen von gelatinehaltigen verdünnten Salzlösungen auf Trägerfolien durchstrahlbare Kristallfolien, die sich zwischen Trägerfolie und Gelatine bildeten. Gute Ergebnisse lieferte auch die Methode der Vakuumtrocknung nach Hibi und Y ADA $^{6}$. Nach Möllenstedt, GrafF und Speidel ${ }^{7}$ kristallisieren dünne Schichten von $\mathrm{KCl}$ aus einem Film verdünnter Lösung aus, der sich zwischen zwei aufeinandergepreßten, vorher mit Kohle bedampften Glasträgern ausbildet. Weitere spezielle Verfahren sind in ${ }^{8}$ und ${ }^{9}$ angegeben.

5 T. Komoda u. S. Sakata, J. Electronmicroscopy (Tokyo) 7, 27 [1959].

6 T. Hibi u. K. Y ADA, J. Electronmicroscopy (Tokyo) 9, 101 [1960].

7 G. Möllenstedt, K. Graff u. R. Speidel, Z. Phys. 167, 367 [1962].

${ }^{8}$ H. M. Montagu-Pollock, Proc. Roy. Soc., Lond. 269, 219 [1962].

9 G. A. Bassett, A. J. Forty u. M. R. Tubbs, 5. Intern. Congr. Electron Microscopy, Philadelphia 1962. 